\title{
ANALISIS PENGARUH LINGKUNGAN KERJA, PROMOSI JABATAN DAN KOMPENSASI TERHADAP KINERJA KARYAWAN PADA CV. KESUMA JAYA MEDAN
}

\author{
Sahat Simbolon \\ Dosen Pascasarjana Institut Bisnis IT\& B Medan Indonesia \\ Email : sahats_simbolon@yahoo.com
}

\begin{abstract}
This study aims to determine the effect of working environment, job promotion and compensation on the employee's performance at CV. Kesuma Jaya Medan. This research is conducted at CV. Kesuma Jaya Medan for 8 (eight) months periode of time, starting from January 2019 until August 2019. This study is using stratified random sampling method. The population in this study is the employees in CV. Kesuma Jaya Medan as many as 106 people. The number of sample obtained is 84 people. Methods of data collection in this study is using questionnaires to collect the data for working environment, job promotion, compensation and employee's performance variable. The technique of data analysis used is validation test, reliability test, description analysis, classic assumption test, multiple linear regression analysis, multiple linear correlation coefficient testhypotesis test partially and simultaneously and coefficient determination. From the description analysis of working environment, job promotion, compensation and employee's performance variable have been in good category. Partially, working environment, job promotion and compensation has a positive and significant effect on employee's performance in CV. Kesuma Jaya Medan in which $t_{\text {count }} \geq t_{\text {table }}$ Simultaneously, there is a positive and significant effect of working environment, job promotion and compensation on employee's performance in $C V$. Kesuma Jaya Medan in which $F_{\text {count }} \geq F_{\text {table. }}$. From the coefficient of determination, employee's performance influenced by working environment, job promotion and compensation by 0,728 or $72,8 \%$. While the remaining 0,272 or 27,2\% of employee's performance is influenced by other variables that are not observed in this study, example leadership, working comitment, organizational culture, etc.
\end{abstract}

Keywords : Working Environment, Job Promotion, Compensation and Employee's Performance.

\section{PENDAHULUAN}

Secara etimologis manajemen berasal dari bahasa Perancis Kuno yaitu ménagement, yang dapat diartikan sebagai seni melaksanakan dan mengatur. Sedangkan secara terminologis para ahli memberikan pendapat yang berbeda tetapi memiliki substansi arti yang sama yaitu proses perencanaan, pengorganisasian, pelaksanaan dan evaluasi untuk mencapai tujuan organisasi.Hasibuan (2016:10) menyatakan manajemen adalah ilmu dan seni mengatur proses pemanfaatan sumber daya manusia dan sumber lainnya secara efektif dan efisien untuk mencapai suatu tujuan tertentu. Sedangkan Schein (2014:2) memberi definisi manajemen sebagai profesi.Manajemen sumber daya manusia merupakan bagian dari ilmu manajemen yang membahas tentang pengaturan tentang peran sumber daya manusia dalam pengelolaan organisasi agar dapat mencapai tujuan. Diantara fungsi manajemen, manajemen sumber daya manusia memiliki cakupan permasalahan yang sangat kompleks, karena menentukan pelaksanaan fungsi dan kegiatan organisasi secara keseluruhan.Sutrisno (2016:5) menyatakan manajemen sumber daya manusia merupakan pengakuan tentang pentingnya tenaga kerja organisasi sebagai sumber daya manusia yang sangat penting dalam memberi kontribusi bagi tujuan-tujuan organisasi dan menggunakan beberapa fungsi dan kegiatan untuk memastikan bahwa SDM tersebut digunakan secara efektif dan adil bagi kepentingan individu, organisasi dan masyarakat.

Pengelolaan dan pengoptimalan sumber daya manusia tidak lepas dari faktor karyawan. Organisasi harus mempunyai karyawan dengan kinerja yang baik. Dengan kata lain kelangsungan suatu organisasi ditentukan oleh kinerja karyawannya.Kinerja karyawan dapat dilihat dari kemampuannya mencapai tujuan yang diharapkan perusahaan. Penentuan tujuan perusahaan yang ditetapkan oleh manajemen perusahaan dari setiap unit organisasi, baik itu pemerintah maupun swasta merupakan 


\section{Volume 20 Nomor 2, September 2020}

strategi untuk meningkatkan kinerja karyawan. Tujuan ini akan memberikan arah dan mempengaruhi bagaimana seharusnya perilaku kerja karyawan yang diharapkan organisasi terhadap setiap karyawan. Namun demikian hal tujuan saja tidak cukup, dibutuhkan ukuran bahwa seorang karyawan telah mencapai kinerja yang diharapkan oleh organisasi.

Organisasi selaku induk kerja harus menyediakan lingkungan kerja yang nyaman dan kondusif yang dapat dijadikan motivasi bagi para karyawan untuk bekerja dengan produktif. Penyediaan lingkungan kerja yang nyaman akan memberikan kepuasan tersendiri kepada karyawan dalam melaksanakan pekerjaannya dan memberikan kesan yang mendalam bagi karyawan yang pada akhirnya karyawan akan mempunyai kinerja yang baik.

Karyawan mengharapkan adanya lingkungan kerja yang nyaman yang bisa memanjakan karyawan dalam bekerja karena lingkungan kerja yang tidak sehat dan nyaman akan menurunkan tingkat produktivitas maupun moral karyawan sehingga akan mempengaruhi tujuan organisasi.Kondisi lingkungan kerja yang tidak sehat dapat menyebabkan para karyawan menjadi mudah stress, tidak semangat untuk bekerja, datang terlambat dan bahkan menyebabkan karyawan mengundurkan diri demikian juga sebaliknya apabila lingkungan kerja itu sehat maka para karyawan tentunya akan semangat dalam bekerja, tidak mudah sakit, mudah untuk konsentrasi sehingga pekerjaan menjadi cepat selesai sesuai dengan target. Tingkat pengunduran diri karyawan pun akan berkurang dan citra perusahaan tentunya akan menjadi baik juga.

Lingkungan kerja sendiri mempunyai dua dimensi, yaitu dimensi fisik dan dimensi non fisik. Dimensi fisik ini dapat berupa pengaturan pewarnaan pada ruangan, pengaturan pencahayaan, kondisi kebersihan ruang kerja, kondisi keamanan dalam bekerja, dan lain sebagainya sedangkan dimensi non fisik dapat berupa kesejahteraan karyawan, suasana lingkungan kerja apakah terdapat pembagian tugas yang jelas, hubungan antar karyawan apakah terjalin komunikasi yang benar baik secara vertikal maupun horizontal, dan lain sebagainya.

Organisasi harus mampu menyediakan kedua dimensi tersebut dalam keadaan baik sehingga mampu membuat para karyawan untuk tetap bekerja secara produktif dammenjalin kerja sama yang baik antar karyawan maupun dengan pimpinan untuk mencapai tujuan organisasi tersebut.

Promosi jabatan yang diterima oleh karyawan diharapkan akan dapat memotivasi karyawan untuk bekerja lebih giat dengan tanggung jawab yang lebih besar. Peningkatan jabatan yang secara otomatis akan meningkatkan pendapatannya secara pribadi akan menjadi motivasi dalam meningkatkan kinerjanya. Karyawan tersebut diharapkan akan secara otomatis akan lebih fokus dalam bekerja secara maksimal untuk perusahaan.

Selain itu, faktor lain yang dapat menghambat kinerja karyawan adalah kompensasi yang diterima oleh karyawan. Handoko (2014:155) menyatakan bahwa kompensasi merupakan segala sesuatu yang diterima oleh pekerja sebagai balasjasa atas kerja mereka. Dalam rangka pemberian kompensasi harus memperhatikan faktor adil dan layak. Apabila pemberian kompensasi kurangtepat, inidapat menyebabkan hal yang kurang menguntungkan bagi perusahaan, dimana kinerja karyawan akan menurun dan sebaliknya jika diberikan secara tepat tujuan perusahaan akan tercapai. Kompensasi yang memadai merupakan alat yang paling ampuh bagi perusahaan untuk mendorong para karyawan bekerja lebih baik. Oleh karena itu kompensasi merupakan motivasi yang dapat menimbulkan minat bagi para karyawan untuk cenderung melakukan kegiatan yang diharapkan oleh perusahaan dalam peningkatan kinerja karyawan.

Tuntutan kinerja yang maksimal dari setiap karyawan juga diharapkan oleh manajemen perusahaan CV. Kesuma Jaya Medan. CV. Kesuma Jaya Medan adalah salah satu perusahaan peleburan besi bekas tua di kota Medan. Untuk dapat meningkatkan hasil produksi besi, perusahaan sangat mengharapkan setiap karyawan untuk memiliki kinerja yang maksimal dan prima. Hal tersebut wajar mengingat bahwa pada tahun 2018 diprediksi konsumsi besi dan baja di Indonesia meningkat sebesar 7\% dan akan terus mengalami peningkatan pada tahun berikutnya (https://finance.detik.com). Dengan kondisi pertumbuhan konsumsi yang meningkat seharusnya CV Kesuma Jaya Medan dapat meningkatkan target penjualan sesuai dengan yang diharapkan. Namun data perusahaan menunjukkan bahwa adanya fluktuasi nilai penjualan perusahaan dimana terjadi trend penurunan produksi besi bekas tua di CV Kesuma Jaya Medan. Berdasarkan data tahun 2016 kinerja perusahaan cukup baik karena kegagalan realisasi produksi hanya sebesar 4,64\%. Namun pada tahun 2017 terjadi peningkatan 


\section{Volume 20 Nomor 2, September 2020}

persentase kegagalan realisasi produksi menjadi 7,64\% kemudian pada tahun 2018 tingkat kegagalan realisasi produksi besi tua meningkat menjadi $25,72 \%$. Jika diamati, hal ini sangat tidak baik bagi kinerja perusahaan secara keseluruhan. Fenomena ini mengindikasi bahwa terdapat kinerja dari karyawan yang memiliki jabatan tertentu yang kurang maksimal.

Menurut persepsi karyawan, terdapat beberapa faktor penyebab turunnya kinerja karyawan seperti lingkungan kerja, promosi jabatan dan kompensasi.Pada lingkungan kerja fisik, faktor kebisingan yang dihadapi oleh karyawan yang disebabkan oleh proses produksi pada dasarnya merupakan permasalahan tersendiri bagi karyawan. Kebisingan yang timbul tersebut mengurangi konsentrasi dan menuntut kehati-hatian yang tinggi dari setiap karyawan dalam bekerja sebab kesalahan sedikit akibat pendengaran yang kurang awas dapat menyebabkan kecelakaan kerja yang fatal. Oleh sebab itu, ruangan yang baik merupakan ruangan yang jauh dari kebisingan. Adapun alternatif yang dapat digunakan untuk ruangan yang bising adalah manajemen dapat menyediakan alat yang dapat meredam suara kebisingan tersebut.Selanjutnya kondisi yang panas juga menyebabkan ketidaknyamanan bagi karyawan dalam bekerja, namun sebagai resiko kerja suka atau tidak suka harus dijalani oleh karyawan sebagai bagian dari proses produksi besi tua. Selain kondisi yang panas, kebersihan juga kurang terjaga karena merupakan tempat peleburan besi tua. Catatan lainnya adalah kondisi perlengkapan keselamatan kerja karyawan yang dirasakan kurang memenuhi standar kerja yang ada. Hal tersebut menjadikan kondisi kinerja karyawan menjadi kurang baik. Oleh sebab itu manajemen dapat mengkondisikan ruangan yang dapat digunakan untuk mengurangi kepanasan bagi karyawan, selain itu kebersihan dan perlengkapan peralatan keamanan kerja juga harus tersedia dan terjaga.

Variabel berikutnya yang diduga menyebabkan terjadi penurunan kinerja karyawan adalah promosi jabatan.Promosi jabatan yang dilakukan oleh manajemen perusahaan kurang objektif. Diketahui bahwa promosi jabatan dilakukan hanya kepada orang-orang dekat dan keluarga pimpinan perusahaan saja. Hal ini sebenarnya terjadi karena perusahaan belum memiliki standar minimal karyawan-karyawan yang berhak secara objektif untuk mendapatkan promosi jabatan dalam peningkatan karirnya atau dengan kata lain, terdapat unsur nepotisme dalam penetapan promosi jabatan. Selain faktor lingkungan kerja dan promosi jabatan, terdapat faktor lain yang menyebabkan penurunan kinerja karyawan yaitu faktor kompensasi.

Menurut persepsi karyawan, faktor kompensasi di perusahaan tersebut kurang memuaskan dimana gaji pokok yang diterima dirasakan masih kurang dari UMK 2019 yang telah ditetapkan oleh pemerintah.. Dari uraian tersebut, penulis tertarik melakukan penelitian dengan judul: "Analisis Pengaruh Lingkungan Kerja, Promosi Jabatan dan Kompensasi Terhadap Kinerja Karyawan Pada CV Kesuma Jaya Medan“.

Berdasarkan identifikasi masalah, dirumuskan masalah penelitian adalah:

1. Bagaimana pelaksanaan lingkungan kerja, promosi jabatan, kompensasi dan kinerja karyawan di CV Kesuma Jaya Medan?

2. Apakah lingkungan kerja berpengaruh positif dan signifikan terhadap kinerja karyawan di CV Kesuma Jaya Medan?

3. Apakah promosi jabatan berpengaruh positif dan signifikan terhadap kinerja karyawan di CV Kesuma Jaya Medan?

4. Apakah kompensasi berpengaruh positif dan signifikan terhadap kinerja karyawan di CV Kesuma Jaya Medan?

5. Apakah lingkungan kerja, promosi jabatan dan kompensasi berpengaruh positif dan signifikan terhadap kinerja karyawan di CV Kesuma Jaya Medan?

\section{TINJAUAN PUSTAKA}

\section{Pengertian Lingkungan Kerja}

Menurut Rivai (2014:165) lingkungan kerja adalah keseluruhan sarana dan prasarana yang ada di sekitar karyawan yang sedang melakukan pekerjaannya. Lingkungan kerja yang kondusif memberikan rasa aman dan memungkinkan para pegawai untuk dapat bekerja secara optimal. Lingkungan kerja dapat mempengaruhi emosi karyawan, dimana jika karyawan senang dengan lingkungan kerjanya maka karyawan tersebut akan merasa nyaman sehingga waktu kerja digunakan secara efektif. 


\section{Volume 20 Nomor 2, September 2020}

Menurut Sedarmayati(2017:1), mendefinisikan lingkungan kerja adalah keseluruhan alat perkakas dan bahan yang dihadapi lingkungan sekitarnya dimana seseorang bekerja mencakup metodekerjanya, serta pengaturan kerjanya baik sebagai perseorangan maupun sebagai kelompok. Lingkungan kerja sebagai keseluruhan sarana prasarana kerja yang ada di sekitar karyawan yang sedang melaksanakan pekerjaan yang dapat mempengaruhi pelaksanaan pekerjaan itu sendiri.

Menurut Sedarmayanti (2017:12) manfaat lingkungan kerja adalah menciptakan gairah kerja, sehingga produktivitas dan prestasi kerja meningkat. Sementara itu, manfaat yang diperoleh karena bekerja dengan orang-orang yang termotivasi adalah pekerjaan dapat terselesaikan dengan tepat, yang artinya pekerjaan diselesaikan sesuai standar yang benar dan dalam skala waktu yang ditentukan. Prestasi kerjanya akan dipantau oleh individu yang bersangkutan, dan tidak akan menimbulkan terlalu banyak pengawasan serta semangat juangnya akan tinggi.

Peningkatan - peningkatan terhadap ini akan meningkatnya produktivitas karena menurunnya jumlah hari yang hilang, meningkatnya efisiensi dan kualitas pekerja yang lebih berkomitmen, menurunnya biaya - biaya kesehatan dan asuransi, tingkat kompensasi pekerja dan pembayaran langsung yang lebih rendah karena menurunnya pengajuan klaim, fleksibilitas dan adaptabilitas yang lebih besar sebagai akibat dari meningkatnya partisipasi dan rasa kepemilikan, rasio seleksi tenaga kerja yang lebih baik karena meningkatnya citra perusahaan yang kemudian perusahaan dapat meningkatkan keuntungan secara subtansial.

\section{Pengertian Promosi Jabatan}

Menurut Siagian (2014:169), promosi adalah apabila seseorang dipindahkan dari satu pekerjaan ke pekerjaan lain yang tanggung jawabnya lebih besar, tingkatan hierarki jabatan lebih tinggi, dan penghasilannya pun lebih besar. Sedangkan menurut Manullang (2014:153), promosi berarti kenaikan jabatan, menerima kekuasaan dan tanggung jawab yang lebih besar dari kekuasaan dan tanggung jawab sebelumnya.

Menurut Hasibuan (2016:108), promosi adalah perpindahan yang memperbesar wewenang dan tanggung jawab karyawan ke jabatan yang lebih tinggi di dalam suatu organisasi sehingga kewajiban, hak, status, dan penghasilannya semakin besar.Menurut Rivai (2014:199) promosi terjadi apabila seorang karyawan dipindahkan dari satu pekerjaan ke pekerjaan lain yang lebih tinggi dalam pembayaran, tanggung jawab, dan atau level.

Siagian (2014:170) mengatakan bahwa organisasi pada umumnya menggunakan dua kriteria utama dalam mempertimbangkan seseorang untuk dipromosikan, yaitu berdasarkann prestasi kerja dan senioritas.Agar promosi para pegawai mempunyai dampak positif bagi organisasi dan semangat para karyawan secara keseluruhan, pendekatan yang paling tepat dalam hal promosi karyawan adalah menggabungkan prestasi kerja dan senioritas.

Menurut Simamora (2014:587) manfaat dari dilakukannya promosi jabatan adalah promosi jabatan memungkinkan perusahaan untuk mendayagunakan keahlian dan kemampuan karyawan setinggi mungkin, promosi jabatan sering kali diberikan kepada karyawan yang berkinerja sangat baik. Karyawan yang dihargai dengan promosi akan termotivasi untuk memberikan kinerja yang lebih tinggi lagi, riset memperlihatkan bahwa kesempatan untuk promosi jabatan dan tingkat kepuasan kerja yang sangat tinggi berkorelasi secara signifikan. Sistem promosi karyawan yang efektif dapat menyebabkan efisiensi organisasional yang lebih besar dan tingkat moral kerja karyawan yang tinggi.

\section{Pengertian Kompensasi}

Menurut Hasibuan (2016:118)"Kompensasi adalah semuapendapatan yang berbentuk uang, barang langsung atau tidak langsungyang diterima karyawan sebagai imbalan atas yang diberikan kepada perusahaan. Sedangkan menurut Handoko (2014:155) Kompensasi adalah segala sesuatuyang diterima olehpekerja sebagaibalasjasaataskerjamereka.

Kompensasi karyawan mempengaruhi produktivitas dan tendensi karyawan untuktetapbersamaperusahaan ataumencaripekerjaanlainnya. Kompensasi yang diberikan kepada karyawan sangat berpengaruh terhadap kinerja karyawan. Tingkat besar kecilnya kompensasi karyawan sangat berkaitan dengan tingkat pendidikan, tingkat jabatan, dan masa kerja karyawan.

Kompensasi merupakan pengeluaran dan biaya bagi perusahaan. Perusahaan mengharapkan agar kompensasi yang dibayarkan memperoleh imbalan prestasi kerja yang lebih besar. Jadi, nilai 


\section{Volume 20 Nomor 2, September 2020}

prestasi kerja karyawan harus lebih besar dari kompensasi yang dibayar perusahaan supaya perusahaan mendapatkan laba dan kontinuitas perusahaan terjamin.

\section{Pengertian Kinerja Karyawan}

Mangkunegara (2014:9) menyatakan bahwa kinerja adalah hasil kerja secara kualitas dan kuantitas yang dicapai oleh seseorang karyawan dalam melaksanakan tugasnya sesuai dengan tanggung jawab yang diberikan kepadanya.Hasibuan (2016:94) berpendapat bahwa kinerja adalah suatu hasil kerja yang dicapai seseorang dalam melaksanakan tugas-tugas yang dibebankan kepadanya yang didasarkan atas kecakapan, pengalaman, dan kesungguhan serta waktu. Sedangkan menurut Handoko (2014:81) kinerja merupakan proses bagi organisasi untuk mengevaluasi atau untuk menilai prestasi kerja karyawan.

Menurut Sugiyono (2015:12) kinerja karyawan dipengaruhi oleh beberapa faktor, antara lain kualitas pekerjaan, kuantitas pekerjaan, pengetahuan pekerjaan, kerja sama tim, kreatifitas, inovasidan inisiatif. Menurut Mahmudi (2015:21) kinerja karyawan dipengaruhi oleh beberapa faktor antara lain faktor personal (Individu), meliputi: pengetahuan, kemampuan,kepercayaan diri, motivasi dan komitmen yang dimiliki oleh setiap individu, faktor kepemimpinan yang meliputi kualitas dalam memberikan dorongan, semangat, arahan, dan dukungan yang diberikan pimpinan; faktor tim yang meliputi kualitas dukungan dan semangat yang diberikan oleh rekan satu tim, kepercayaan terhadap sesama anggota tim, keserataandan kekompakan anggota tim dan faktor sistem, yang meliputi sistem kerja, fasilitas kerja, atau infrastruktur yang diberikan organisasi, proses organisasi dan kultur kerja dalam organisasi.

\section{METODE PENELITIAN}

Penelitian ini dilakukan pada CV. Kesuma Jaya Medan yang beralamat di Jalan Lintas Sumatera No. 368 Cinta Damai Medan Helvetia Kota Medan Sumatera Utara, 20126. Ruang lingkup penelitian ini adalah lingkungan kerja, promosi jabatan, kompensasi dan kinerja karyawan. Populasi dalam penelitian ini adalah seluruh karyawan CV. Kesuma Jaya Medan tahun 2019 sebanyak 106 orang. Teknik penentuan sampel adalah metode stratified random sampling, Jumlah sampel pada penelitian ini ditentukan dengan rumus Slovin yaitu 84 sampel.Teknik pengumpulan data yang digunakan adalahkuesioner dan studi dokumentasi. Teknik analisis data yang digunakan adalahadalah uji validitas, uji reliabilitas, analisis deskriptif, uji asumsi klasik, analisis regresi linear berganda, uji hipotesis parsial atau uji $\mathrm{t}$, uji hipotesis simultan atau uji $\mathrm{F}$ dan perhitungan koefisien determinasi.

\section{Analisis Deskriptif}

\section{HASIL PENELITIAN DAN PEMBAHASAN}

Analisis deskriptif dilakukan untuk mengetahui berapa nilai frekuensi dan persentase yang diperoleh dari masing-masing alternatif jawaban yang diberikan oleh setiap responden dalam kuesioner penelitian. Deskripsi skor penilaian jawaban dari masing-masing variabel di dalam penelitian ini dapat dilihat pada tabel 1. berikut :

Deskripsi skor penilaian jawaban dari variabel lingkungan kerja

Tabel 1. Jumlah dan Persentase Jawaban Responden Tentang Lingkungan Kerja

\begin{tabular}{|c|c|c|c|c|c|c|c|c|c|c|}
\hline \multirow{3}{*}{ Indikator penelitian } & \multicolumn{10}{|c|}{ Jumlah dan persentase jawaban responden } \\
\hline & \multicolumn{2}{|c|}{ SS } & \multicolumn{2}{|c|}{$\mathrm{S}$} & \multicolumn{2}{|c|}{$\mathrm{CS}$} & \multicolumn{2}{|c|}{$\mathrm{TS}$} & \multicolumn{2}{|c|}{ STS } \\
\hline & $\mathrm{F}$ & $\%$ & $\mathrm{~F}$ & $\%$ & $\mathrm{~F}$ & $\%$ & $\mathrm{~F}$ & $\%$ & $\mathrm{~F}$ & $\%$ \\
\hline Pencahayaan yang baik & 38 & 45,2 & 27 & 32,1 & 13 & 15,5 & 6 & 7,1 & 0 & 0,0 \\
\hline Lampu berfungsi dengan baik & 43 & 51,2 & 28 & 33,3 & 4 & 4,8 & 9 & 10,7 & 0 & 0,0 \\
\hline Penerangan nyaman & 41 & 48,8 & 20 & 23,8 & 12 & 14,3 & 11 & 13,1 & 0 & 0,0 \\
\hline $\begin{array}{l}\text { Sirkulasi udara berfungsi dengan } \\
\text { baik }\end{array}$ & 29 & 34,5 & 31 & 36,9 & 24 & 28,6 & 0 & 0,0 & 0 & 0,0 \\
\hline $\begin{array}{l}\text { Penyejuk ruangan berfungsi } \\
\text { dengan baik }\end{array}$ & 48 & 57,1 & 19 & 22,6 & 12 & 14,3 & 5 & 6,0 & 0 & 0,0 \\
\hline
\end{tabular}




\section{Volume 20 Nomor 2, September 2020}

\begin{tabular}{|l|c|c|c|c|c|c|c|c|c|c|}
\hline Ruangan kerja tidak bising & 31 & 36,9 & 27 & 32,1 & 26 & 31,0 & 0 & 0,0 & 0 & 0,0 \\
\hline Ruangan kerja kedap suara & 37 & 44,0 & 30 & 35,7 & 13 & 15,5 & 4 & 4,8 & 0 & 0,0 \\
\hline Cat membuat ruangan terang & 42 & 50,0 & 10 & 11,9 & 25 & 29,8 & 7 & 8,3 & 0 & 0,0 \\
\hline Kombinasi warna cat sesuai & 41 & 48,8 & 27 & 32,1 & 16 & 19,0 & 0 & 0,0 & 0 & 0,0 \\
\hline Ruang kerja luas & 44 & 52,4 & 17 & 20,2 & 22 & 26,2 & 1 & 1,2 & 0 & 0,0 \\
\hline Tata letak ruangan tepat & 30 & 35,7 & 30 & 35,7 & 24 & 28,6 & 0 & 0,0 & 0 & 0,0 \\
\hline Peralatan keamanan lengkap & 45 & 53,6 & 25 & 29,8 & 9 & 10,7 & 5 & 6,0 & 0 & 0,0 \\
\hline Terdapat security & 35 & 41,7 & 30 & 35,7 & 19 & 22,6 & 0 & 0,0 & 0 & 0,0 \\
\hline $\begin{array}{l}\text { Tingkat siap siaga } \\
\text { penanggulangan kecelakaan } \\
\text { kerja tinggi }\end{array}$ & 36 & 42,9 & 23 & 27,4 & 18 & 21,4 & 7 & 8,3 & 0 & 0,0 \\
\hline Total & 540 & 642,8 & 344 & 409,4 & 237 & 282,3 & 55 & 65,5 & 0 & 0,0 \\
\hline Rata-rata & & 45,9 & & 29,2 & & 20,2 & & 4,7 & & \\
\hline
\end{tabular}

Sumber: Data Diolah Dari Hasil Penelitian, 2019

Berdasarkan tabel 1. dapat diketahui bahwa responden yang memilih jawaban sangat setuju adalah sebanyak 45,9\%; responden yang memilih jawaban setuju adalah sebanyak $29,2 \%$; responden yang memilih jawaban kurang setuju adalah sebanyak $20,2 \%$; responden yang memilih jawaban tidak setuju adalah sebanyak 4,7\%.Dari keseluruhan jawaban responden terdapat $75,1 \%$ responden yang memilih jawaban sangat setuju dan jawaban setuju dimana persentase jawaban tersebut berada di antara skor penilaian antara 70 sampai dengan 79 . Hal ini menunjukkan bahwa lingkungan kerja dalam perusahaan ini dikategorikan baik, sedangkan dari keseluruhan jawaban responden terdapat 4,7\% responden yang memilih jawaban tidak setuju.

Deskripsi skor penilaian jawaban dari variabel promosi jabatan Tabel 2. Jumlah dan Persentase Jawaban Responden Tentang Promosi Jabatan

\begin{tabular}{|c|c|c|c|c|c|c|c|c|c|c|}
\hline \multirow{3}{*}{ Indikator penelitian } & \multicolumn{10}{|c|}{ Jumlah dan persentase jawaban responden } \\
\hline & \multicolumn{2}{|c|}{ SS } & \multicolumn{2}{|c|}{$\mathrm{S}$} & \multicolumn{2}{|c|}{$\mathrm{CS}^{\mathrm{y}}$} & \multicolumn{2}{|c|}{ TS } & \multicolumn{2}{|c|}{ STS } \\
\hline & $\mathrm{F}$ & $\%$ & $\mathrm{~F}$ & $\%$ & $\mathrm{~F}$ & $\%$ & $\mathrm{~F}$ & $\%$ & $\mathrm{~F}$ & $\%$ \\
\hline $\begin{array}{l}\text { Standar penilaian kejujuran } \\
\text { karyawan }\end{array}$ & 23 & 27,4 & 35 & 41,7 & 26 & 31,0 & 0 & 0,0 & 0 & 0,0 \\
\hline $\begin{array}{l}\text { Laporan kerja yang disusun } \\
\text { sesuai yang terealisasi }\end{array}$ & 23 & 27,4 & 46 & 54,8 & 14 & 16,7 & 1 & 1,2 & 0 & 0,0 \\
\hline $\begin{array}{l}\text { Manajemen memiliki catatan } \\
\text { kedisiplinan karyawan }\end{array}$ & 17 & 20,2 & 53 & 63,1 & 13 & 15,5 & 1 & 1,2 & 0 & 0,0 \\
\hline $\begin{array}{l}\text { Menegakkan aturan } \\
\text { kedisiplinan secara adil }\end{array}$ & 24 & 28,6 & 38 & 45,2 & 21 & 25,0 & 1 & 1,2 & 0 & 0,0 \\
\hline Sanksi bagi yang tidak disiplin & 24 & 28,6 & 32 & 38,1 & 26 & 31,0 & 2 & 2,4 & 0 & 0,0 \\
\hline $\begin{array}{l}\text { Karyawan mampu mencapai } \\
\text { target }\end{array}$ & 21 & 25,0 & 30 & 35,7 & 30 & 35,7 & 3 & 3,6 & 0 & 0,0 \\
\hline Kerjasama tim baik & 21 & 25,0 & 40 & 47,6 & 16 & 19,0 & 7 & 8,3 & 0 & 0,0 \\
\hline Kerjasama antar lini baik & 15 & 17,9 & 38 & 45,2 & 20 & 23,8 & 11 & 13,1 & 0 & 0,0 \\
\hline $\begin{array}{l}\text { Menyelesaikan pekerjaan } \\
\text { dengan efektif }\end{array}$ & 18 & 21,4 & 40 & 47,6 & 21 & 25,0 & 5 & 6,0 & 0 & 0,0 \\
\hline $\begin{array}{l}\text { Menyelesaikan pekerjaan } \\
\text { dengan efisien }\end{array}$ & 22 & 26,2 & 43 & 51,2 & 16 & 19,0 & 3 & 3,6 & 0 & 0,0 \\
\hline Penilaian kemampuan bekerja & 21 & 25,0 & 37 & 44,0 & 22 & 26,2 & 4 & 4,8 & 0 & 0,0 \\
\hline $\begin{array}{l}\text { Tingkat pengunduran diri } \\
\text { rendah }\end{array}$ & 18 & 21,4 & 33 & 39,3 & 27 & 32,1 & 6 & 7,1 & 0 & 0,0 \\
\hline $\begin{array}{l}\text { Menjalankan tugas dari } \\
\text { pimpinan }\end{array}$ & 23 & 27,4 & 36 & 42,9 & 21 & 25,0 & 4 & 4,8 & 0 & 0,0 \\
\hline $\begin{array}{l}\text { Sifat kepemimpinan dijadikan } \\
\text { panutan. }\end{array}$ & 15 & 17,9 & 40 & 47,6 & 28 & 33,3 & 1 & 1,2 & 0 & 0,0 \\
\hline
\end{tabular}




\section{Volume 20 Nomor 2, September 2020}

\begin{tabular}{|l|c|c|c|c|c|c|c|c|c|c|}
\hline Komunikasi vertikal baik & 19 & 22,6 & 43 & 51,2 & 19 & 22,6 & 3 & 3,6 & 0 & 0,0 \\
\hline Komunikasi horizontal baik & 13 & 15,5 & 38 & 45,2 & 30 & 35,7 & 3 & 3,6 & 0 & 0,0 \\
\hline Tidak terjadi miskomunikasi & 23 & 27,4 & 39 & 46,4 & 17 & 20,2 & 5 & 6,0 & 0 & 0,0 \\
\hline $\begin{array}{l}\text { Jenjang pendidikan formal } \\
\text { karyawan }\end{array}$ & 21 & 25,0 & 39 & 46,4 & 24 & 28,6 & 0 & 0,0 & 0 & 0,0 \\
\hline Total & 361 & 429,9 & 700 & 833,2 & 391 & 465,4 & 60 & 71,7 & 0 & 0 \\
\hline Rata-rata & & 23,9 & & 46,3 & & 25,9 & & 3,9 & & 0,0 \\
\hline
\end{tabular}

Sumber: Data Diolah Dari Hasil Penelitian, 2019

Berdasarkan tabel 2. dapat diketahui bahwa responden yang memilih jawaban sangat setuju adalah sebanyak $23,9 \%$; responden yang memilih jawaban setuju adalah sebanyak 46,3\%; responden yang memilih jawaban kurang setuju adalah sebanyak 25,9\%; responden yang memilih jawaban tidak setuju adalah sebanyak 3,9\%.Dari keseluruhan jawaban responden terdapat 70,2\% responden yang memilih jawaban sangat setuju dan jawaban setuju dimana persentase jawaban tersebut berada di antara skor penilaian antara 70 sampai dengan 79 . Hal ini menunjukkan bahwa promosi jabatandalam perusahaan ini dikategorikan baik, sedangkan dari keseluruhan jawaban responden terdapat 3,9\% responden yang memilih jawaban tidak setuju.

\section{Deskripsi skor penilaian jawaban dari variabel kompensasi}

Tabel 3. Jumlah dan Persentase Jawaban Responden Tentang Kompensasi

\begin{tabular}{|c|c|c|c|c|c|c|c|c|c|c|}
\hline \multirow{3}{*}{ Indikator penelitian } & \multicolumn{10}{|c|}{ Jumlah dan persentase jawaban responden } \\
\hline & \multicolumn{2}{|c|}{ SS } & \multicolumn{2}{|c|}{$\mathrm{S}$} & \multicolumn{2}{|c|}{ CS } & \multicolumn{2}{|c|}{ TS } & \multicolumn{2}{|c|}{ STS } \\
\hline & $\mathrm{F}$ & $\%$ & $\mathrm{~F}$ & $\%$ & $F$ & $\%$ & $\mathrm{~F}$ & $\%$ & $\mathrm{~F}$ & $\%$ \\
\hline Gaji cukup memenuhi kebutuhan & 45 & 53,6 & 15 & 17,9 & 14 & 16,7 & 10 & 11,9 & 0 & 0,0 \\
\hline $\begin{array}{l}\text { Gaji seimbang dengan hasil } \\
\text { pekerjaan }\end{array}$ & 42 & 50,0 & 19 & 22,6 & 14 & 16,7 & 9 & 10,7 & 0 & 0,0 \\
\hline Tidak ada potongan upah & 50 & 59,5 & 11 & 13,1 & 20 & 23,8 & 3 & 3,6 & 0 & 0,0 \\
\hline Insentif sesuai prestasi & 37 & 44,0 & 21 & 25,0 & 23 & 27,4 & 3 & 3,6 & 0 & 0,0 \\
\hline Bonus tahunan & 31 & 36,9 & 22 & 26,2 & 27 & 32,1 & 4 & 4,8 & 0 & 0,0 \\
\hline Hak cuti tahunan & 34 & 40,5 & 25 & 29,8 & 25 & 29,8 & 0 & 0,0 & 0 & 0,0 \\
\hline Cuti sakit & 42 & 50,0 & 18 & 21,4 & 24 & 28,6 & 0 & 0,0 & 0 & 0,0 \\
\hline Premi kecelakaan & 53 & 63,1 & 12 & 14,3 & 16 & 19,0 & 3 & 3,6 & 0 & 0,0 \\
\hline Asuransi kesehatan & 58 & 69,0 & 18 & 21,4 & 8 & 9,5 & 0 & 0,0 & 0 & 0,0 \\
\hline Acara kekeluargaan & 55 & 65,5 & $21 \mathrm{H}$ & 25,0 & 8 & 9,5 & 0 & 0,0 & 0 & 0,0 \\
\hline $\begin{array}{l}\text { Pembelaan kepada karyawan yang } \\
\text { tersangkut hukum karena } \\
\text { pekerjaannya }\end{array}$ & 38 & 45,2 & 37 & 44,0 & 9 & 10,7 & 0 & 0,0 & 0 & 0,0 \\
\hline Total & 485 & 577,3 & 219 & 260,7 & 188 & 223,8 & 32 & 38,2 & 0 & 0,0 \\
\hline Rata-rata & & 52,5 & & 23,7 & & 20,3 & & 3,5 & & 0.0 \\
\hline
\end{tabular}

Sumber: Data Diolah Dari Hasil Penelitian, 2019

Berdasarkan tabel 3. dapat diketahui bahwa responden yang memilih jawaban sangat setuju adalah sebanyak 52,5\%; responden yang memilih jawaban setuju adalah sebanyak $23,7 \%$; responden yang memilih jawaban kurang setuju adalah sebanyak 20,3\%; responden yang memilih jawaban tidak setuju adalah sebanyak 3,5\%. Dari keseluruhan jawaban responden terdapat 76,2\% responden yang memilih jawaban sangat setuju dan jawaban setuju dimana persentase jawaban tersebut berada di antara skor penilaian antara 70 sampai dengan 79. Hal ini menunjukkan bahwa kompensasidalam perusahaan ini dikategorikan baik, sedangkan dari keseluruhan jawaban responden terdapat 3,5\% responden yang memilih jawaban tidak setuju.

\section{Deskripsi skor penilaian jawaban dari variabel KinerjaKaryawan}

Tabel 4. Jumlah dan Persentase Jawaban Responden Tentang KinerjaKaryawan

\begin{tabular}{|c|c|c|c|c|c|c|c|c|c|c|}
\hline \multirow{3}{*}{ Indikator penelitian } & \multicolumn{10}{|c|}{ Jumlah dan persentase jawaban responden } \\
\hline & \multicolumn{2}{|c|}{ SS } & \multicolumn{2}{|c|}{$\mathrm{S}$} & \multicolumn{2}{|c|}{$\mathrm{CS}$} & \multicolumn{2}{|c|}{ TS } & \multicolumn{2}{|c|}{ STS } \\
\hline & $\mathrm{F}$ & $\%$ & $\mathrm{~F}$ & $\%$ & $\mathrm{~F}$ & $\%$ & $F$ & $\%$ & $\mathrm{~F}$ & $\%$ \\
\hline Menyelesaikan pekerjaan tepat waktu & 31 & 36,9 & 26 & 31,0 & 16 & 19,0 & 11 & 13,1 & 0 & 0,0 \\
\hline
\end{tabular}


Volume 20 Nomor 2, September 2020

\begin{tabular}{|l|c|c|c|c|c|c|c|c|c|c|}
\hline Melakukan evaluasi pekerjaan & 29 & 34,5 & 31 & 36,9 & 24 & 28,6 & 0 & 0,0 & 0 & 0,0 \\
\hline Berperilaku baik & 35 & 41,7 & 24 & 28,6 & 25 & 29,8 & 0 & 0,0 & 0 & 0,0 \\
\hline Bersikap ramah tamah & 34 & 40,5 & 16 & 19,0 & 34 & 40,5 & 0 & 0,0 & 0 & 0,0 \\
\hline Bertanggung jawab & 36 & 42,9 & 17 & 20,2 & 23 & 27,4 & 8 & 9,5 & 0 & 0,0 \\
\hline $\begin{array}{l}\text { Kesesuaian kompetensi dengan } \\
\text { pekerjaan }\end{array}$ & 32 & 38,1 & 27 & 32,1 & 25 & 29,8 & 0 & 0,0 & 0 & 0,0 \\
\hline Memiliki keterampilan & 40 & 47,6 & 27 & 32,1 & 17 & 20,2 & 0 & 0,0 & 0 & 0,0 \\
\hline Memiliki pengetahuan & 16 & 19,0 & 63 & 75,0 & 5 & 6,0 & 0 & 0,0 & 0 & 0,0 \\
\hline $\begin{array}{l}\text { Kesempatan meningkatkan } \\
\text { kompetensi }\end{array}$ & 17 & 20,2 & 62 & 73,8 & 5 & 6,0 & 0 & 0,0 & 0 & 0,0 \\
\hline Perhatian pada potensi karyawan & 17 & 20,2 & 55 & 65,5 & 12 & 14,3 & 0 & 0,0 & 0 & 0,0 \\
\hline Total & 287 & 341,6 & 348 & 414,2 & 186 & 221,6 & 19 & 22,6 & 0 & 0 \\
\hline Rata-rata & & 34,1 & & 41,4 & & 22,2 & & 2,3 & & 0,0 \\
\hline
\end{tabular}

Sumber: Data Diolah Dari Hasil Penelitian, 2019

Berdasarkan tabel 4. dapat diketahui bahwa responden yang memilih jawaban sangat setuju adalah sebanyak $34,1 \%$; responden yang memilih jawaban setuju adalah sebanyak $41,4 \%$; responden yang memilih jawaban kurang setuju adalah sebanyak $22,2 \%$; responden yang memilih jawaban tidak setuju adalah sebanyak 2,3\%.Dari keseluruhan jawaban responden terdapat 75,5\% responden yang memilih jawaban sangat setuju dan jawaban setuju dimana persentase jawaban tersebut berada di antara skor penilaian antara 70 sampai dengan 79 . Hal ini menunjukkan bahwa kinerja karyawandalam perusahaan ini dikategorikan baik, sedangkan dari keseluruhan jawaban responden terdapat 2,3\% responden yang memilih jawaban tidak setuju.

Skor Penilaian dari Persentase Jawaban Responden untuk Setiap Butir Pernyataan dalam Kuesioner Variabel Lingkungan Kerja, Promosi Jabatan, Kompensasi, dan Kinerja Karyawan dapat dilihat pada tabel 5. berikut:

Tabel 5. Skor Penilaian dari Persentase Jawaban Responden untuk Setiap Butir Pernyataan dalam Kuesioner Variabel Lingkungan Kerja, Promosi Jabatan, Kompensasi, dan Kinerja Karyawan.

\begin{tabular}{|l|c|c|}
\hline \multicolumn{1}{|c|}{ Instumen } & Skor Penilaian & Kategori \\
\hline Lingkungan Kerja & 75,1 & Baik \\
\hline Promosi Jabatan & 70,2 & Baik \\
\hline Kompensasi & 76,2 & Baik \\
\hline Kinerja Karyawan & 75,5 & Baik \\
\hline
\end{tabular}

Sumber : Data Diolah Dari Hasil Penelitian, 2019

\section{Uji Normalitas}

Hasil uji normalitas untuk variabel lingkungan kerja, variabel promosi jabatan, variabel kompensasi, dan variabel kinerja karyawan dengan menggunakan probability plot dapat dilihat pada gambar 1 . berikut: 


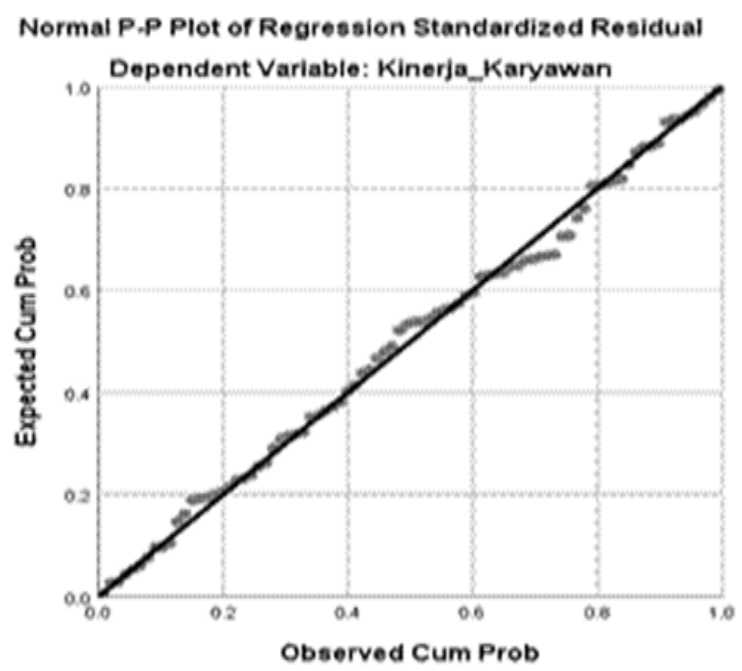

Gambar 1. Grafik Normalitas untuk Variabel Lingkungan Kerja, Promosi Jabatan dan Kompensasi terhadap Kinerja Karyawan

Sumber: Data Diolah Dari Hasil Penelitian, 2019

Dari gambar 1. dapat disimpulkan bahwa model yang digunakan menunjukkan indikasi normal, dimana analisis dari grafik di atas terlihat titik-titik menyebar di sekitar garis diagonal, serta penyebaraanya mengikuti arah garis diagonal.Selain dari probability plot, uji normalitas dapat dilihat dengan uji Kolmogorov Smirnov seperti pada tabel 6. berikut:

Tabel 6. Hasil Uji Normalitas Untuk Variabel Lingkungan Kerja, Variabel Promosi Jabatan, Variabel Kompensasi dan Variabel Kinerja Karyawan One-Sample Kolmogorov-Smirnov Test

\begin{tabular}{|l|l|r|}
\hline \multicolumn{2}{|c|}{ One-Sample Kolmogorov-Smirnov Test } \\
\hline \multicolumn{2}{|l|}{} & Unstandardized Residual \\
\hline $\mathrm{N}$ & Mean & 84 \\
\cline { 2 - 4 } Normal Parameters ${ }^{\text {a,b }}$ & Std. Deviation & .0000000 \\
\hline \multirow{2}{*}{ Most Extreme Differences } & Absolute & .37341310 \\
\cline { 2 - 3 } & Positive & .064 \\
\cline { 2 - 3 } & Negative & .064 \\
\hline \multicolumn{2}{|l|}{ Test Statistic } & .046 \\
\hline Asymp. Sig. (2-tailed) & .064 \\
\hline a. Test distribution is Normal. & $.200^{\text {c,d }}$ \\
\hline b. Calculated from data. & \\
\hline c. Lilliefors Significance Correction. \\
\hline \multicolumn{2}{|l|}{ d. This is a lower bound of the true significance. } \\
\hline
\end{tabular}

Sumber : Data Diolah Dari Hasil Penelitian, 2019

Berdasarkan tabel 6. dapat diketahui bahwa nilai $\mathrm{p}$ value Sig atau nilai signifikansi adalah sebesar 0,200, dimana nilai $p$ value Sig atau nilai signifikansi yang dihasilkan adalah >0,05, maka dapat disimpulkan bahwa data yang diuji di dalam penelitian ini adalah berdistribusi normal.

\section{Uji Multikolinearitas}

Hasil uji multikolinearitas untuk pengaruh di antara variabel lingkungan kerja, promosi jabatan dankompensasi terhadap variabel kinerja karyawan adalah dapat dilihat pada tabel 7. berikut : 
Tabel 7.Hasil Uji Multikolinearitas Untuk Pengaruh di antara Variabel Lingkungan Kerja, Variabel Promosi Jabatan dan Variabel Kompensasi terhadap Variabel Kinerja Karyawan Coefficients $^{\mathrm{a}}$

\begin{tabular}{|c|c|c|c|c|c|c|c|}
\hline \multirow[t]{2}{*}{ Model } & \multicolumn{2}{|c|}{$\begin{array}{l}\text { Unstandardized } \\
\text { Coefficients }\end{array}$} & \multirow{2}{*}{$\begin{array}{c}\begin{array}{c}\text { Standardized } \\
\text { Coefficients }\end{array} \\
\text { Beta }\end{array}$} & \multirow[t]{2}{*}{$\mathrm{t}$} & \multirow[t]{2}{*}{ Sig } & \multicolumn{2}{|c|}{$\begin{array}{c}\text { Collinearity } \\
\text { Statistics }\end{array}$} \\
\hline & $\mathrm{B}$ & Std. Error & & & & Tolerance & VIF \\
\hline 1 (Constant) & 10,380 & 2,386 & & 4,349 & ,000 & & \\
\hline Lingkungan_Kerja & , 158 &, 058 & ,285 & 2,726 & ,008 & ,299 & 3,340 \\
\hline Promosi_Jabatan & ,194 & ,039 & ,475 & 4,999 &, 000 & ,363 & 2,755 \\
\hline Kompensasi &, 160 & ,073 & , 182 & 2,212 &, 030 & ,483 & 2,071 \\
\hline
\end{tabular}

a. Kinerja_Karyawan

Sumber : Data Diolah Dari Hasil Penelitian, 2019

Berdasarkan tabel 7. dapat diketahui bahwa nilai tolerance dari hasil uji multikolinearitas untuk variabel lingkungan kerja $\left(X_{1}\right)$ sebesar 0,299; variabel promosi jabatan $\left(X_{2}\right)$ sebesar 0,363 dan variabel kompensasi $\left(\mathrm{X}_{3}\right)$ adalah 0,483 . Nilai VIF dari hasil uji multikolinearitas untuk variabel lingkungan $\operatorname{kerja}\left(\mathrm{X}_{1}\right)$ adalah 3,340; variabel promosi jabatan $\left(\mathrm{X}_{2}\right)$ adalah 2,755 dan variabel kompensasi $\left(\mathrm{X}_{3}\right)$ adalah 2,071 dimana nilai tolerance yang dihasilkan adalah $>0,10$ dan nilai VIF yang dihasilkan adalah $<10$, maka dapat disimpulkan bahwa tidak terjadi multikolinearitas atau tidak ditemukan adanya korelasi di antara variabel bebas yaitu lingkungan kerja, promosi jabatan dan kompensasi dalam model regresi di dalam penelitian ini.

\section{Uji Heterokedastisitas}

Hasil uji heterokedastisitas dapat dilihat melalui pola gambar Scatterplotspada gambar 2. berikut:

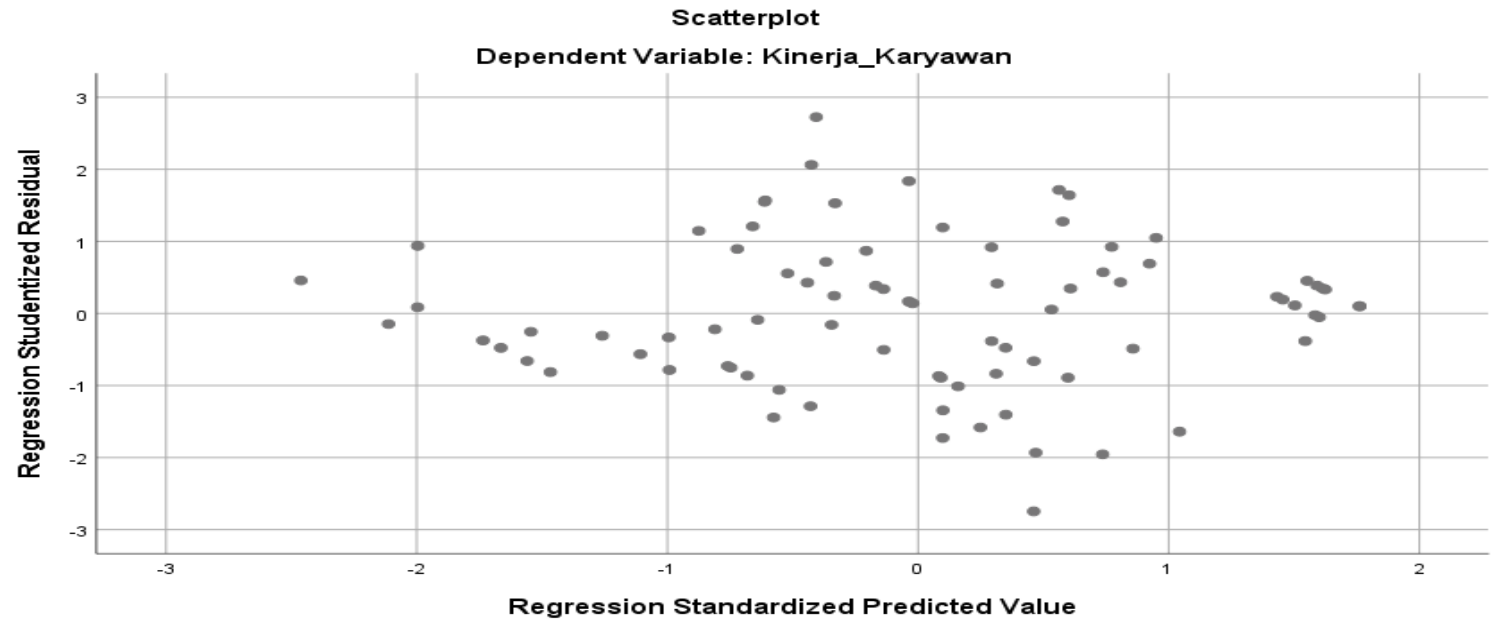

Gambar 2. : Grafik Heterokedastisitasuntuk Variabel Lingkungan Kerja, Promosi Jabatan dan Kompensasi terhadap Kinerja Karyawan

Berdasarkan gambar 2. terlihat titik-titik menyebar secara acak, tidak membentuk pola tertentu yang jelas, serta tersebar baik diatas maupun dibawah angka 0 pada sumbu Y. Hal ini berarti tidak terjadi heterokedastisitas pada model regresi ini.Selain dengan pola gambar Scatterplot, uji heterokedastisitas dapat dilakukan dengan metode glejser seperti tabel 8. berikut:

Tabel 8. Pengujian Heteroskedastisitasuntuk Variabel Lingkungan Kerja, Promosi Jabatan dan Kompensasi terhadap Kinerja Karyawan

\begin{tabular}{|l|c|c|c|c|c|}
\hline \multicolumn{6}{|c|}{ Coefficients $^{\mathrm{a}}$} \\
\hline Model & \multicolumn{2}{|c|}{ Unstandardized Coefficients } & $\begin{array}{c}\text { Standardized } \\
\text { Coefficients }\end{array}$ & $\mathrm{t}$ & Sig. \\
\cline { 2 - 5 } & B & Std. Error & Beta & \\
\hline
\end{tabular}




\section{Volume 20 Nomor 2, September 2020}

\begin{tabular}{|l|l|r|r|r|r|r|}
\hline \multirow{3}{*}{1} & (Constant) & 2.810 & 1.453 & & 1.934 & .057 \\
\cline { 2 - 7 } & Lingkungan_Kerja & .007 & .035 & .040 & .194 & .847 \\
\cline { 2 - 7 } & Promosi_Jabatan & .002 & .024 & .012 & .067 & .947 \\
\cline { 2 - 7 } & Kompensasi & -.031 & .044 & -.113 & -.704 & .484 \\
\hline
\end{tabular}

\section{Sumber: Data Diolah Dari Hasil Penelitian, 2019}

Berdasarkan pada Tabel 8. diketahui bahwa nilai sig lingkungan kerja adalah sebesar 0,847, nilai sig promosi jabatan adalah sebesar 0,947 dan nilai sig kompensasi adalah sebesar 0,484 . Nilai sig tersebut lebih besar dari 0,05 sehingga dapat disimpulkan bahwa data penelitian ini telah bebas gejala heteroskedastisitas.

Analisis Regresi Linear Berganda

Hasil analisis regresi linear berganda untuk pengaruh di antara variabel lingkungan kerja, variabel promosi jabatan dan variabel kompensasi terhadap variabel kinerja karyawan dapat dilihat pada tabel 7 di atas.

Berdasarkan tabel 7 di atas. dapat diketahui bahwa koefisien a adalah 10,380; koefisien $b_{1}$ adalah 0,158; koefisien $b_{2}$ adalah 0,194 dan koefisien $b_{3}$ adalah 0,160. Koefisien a merupakan konstanta atau besarnya nilai variabel kinerja karyawan apabila nilai variabel lingkungan kerja, promosi jabatan dan kompensasi $=0$, sedangkan koefisien $\mathrm{b}$ adalah nilai koefisien regresi masing-masing variabel $\mathrm{X}$.

Berdasarkan tabel 10. dapat diketahui bahwa nilai komponen a atau konstanta sebesar 10,380merupakan nilai $Y$ apabila nilai $X_{1}, X_{2}$ dan nilai $X_{3}=0$; nilai komponen $b_{1}$ atau koefisien regresi untuk variabel lingkungan kerja sebesar 0,158 menandakan bahwa variabel lingkungan kerja mempunyai hubungan yang searah dengan variabel kinerja karyawan yang artinya semakin baik lingkungan kerja yang diterapkan oleh pimpinan perusahaan terhadap bawahan, maka kinerja yang dihasilkan oleh karyawan akan semakin meningkat, sebaliknya semakin kurang baik lingkungan kerja yang diterapkan oleh pimpinan perusahaan, maka kinerja yang dihasilkan oleh karyawan akan semakin menurun.

Nilai komponen $b_{2}$ atau koefisien regresi untuk variabel promosi jabatansebesar 0,194 menandakan bahwa variabel promosi jabatan mempunyai hubungan yang searah dengan variabel kinerja karyawan yang artinya semakin jelassistempromosi jabatan yang diterapkan oleh pimpinan perusahaan, maka kinerja yang dihasilkan oleh karyawan akan semakin meningkat, sebaliknya semakin lemahsistem promosi jabatan yang diterapkan oleh pimpinan perusahaan, maka kinerja yang dihasilkan oleh karyawan akan semakin menurun.

Nilai komponen $b_{3}$ atau koefisien regresi untuk variabel kompensasi sebesar 0,160 menandakan bahwa variabel kompensasi mempunyai hubungan yang searah dengan variabel kinerja karyawan yang artinya semakin tinggi kompensasi yang dirasakan oleh karyawan, maka karyawan akan menunjukkan kinerja yangsemakin meningkat, sebaliknya semakin rendah kompensasi yang dirasakan oleh karyawan, maka kinerja karyawan semakin menurun.

Berdasarkan hasil perhitungan uji signifikansi di dalam analisis regresi linear berganda diketahui bahwa nilai $\mathrm{p}$ value Sig atau nilai signifikansi dari pengaruh di antara variabel lingkungan kerja terhadap variabel kinerja karyawan adalah 0,008 dimana nilai $\mathrm{p}$ value Sig atau nilai signifikansi yang dihasilkan adalah $<0,05$, maka dapat disimpulkan bahwa regresi pengaruh di antara variabel lingkungan kerjaterhadap variabel kinerja karyawan di dalam penelitian ini adalah signifikan. Nilai $\mathrm{p}$ value sig atau nilai signifikansi dari pengaruh di antara variabel promosi jabatan terhadap variabel kinerja karyawan adalah 0,000 dimana nilai $p$ value sig atau nilai signifikansi yang dihasilkan adalah < 0,05 , maka dapat disimpulkan bahwa regresi pengaruh di antara variabel promosi jabatan terhadap variabel kinerja karyawan di dalam penelitian ini adalah signifikan. Nilai $\mathrm{p}$ value sig atau nilai signifikansi dari pengaruh di antara variabel kompensasi terhadap variabel kinerja karyawan adalah 0,030 dimana nilai $\mathrm{p}$ value sig atau nilai signifikansi yang dihasilkan adalah $<0,05$, maka dapat disimpulkan bahwa regresi pengaruh di antara variabel kompensasi terhadap variabel kinerja karyawan di dalam penelitian ini signifikan.

\section{Uji Koefisien Korelasi Linear Berganda}

Hasil uji koefisien korelasi linear berganda untuk pengaruh di antara variabel lingkungan kerja, promosi jabatan, kompensasi terhadap variabel kinerja karyawandapat dilihat pada tabel 9 . berikut : 


\section{Volume 20 Nomor 2, September 2020}

Tabel 9. Hasil Uji Koefisien Korelasi Linear Berganda untuk Pengaruh di antara Variabel Lingkungan Kerja, Promosi Jabatan, dan Kompensasi terhadap Kinerja Karyawan Model Summary

\begin{tabular}{|l|r|r|r|r|}
\hline \multicolumn{1}{|c|}{ Model } & \multicolumn{1}{c|}{ R } & \multicolumn{1}{c|}{ R Square } & \multicolumn{1}{c|}{ Adjusted R Square } & \multicolumn{1}{c|}{ Std. Error of the Estimate } \\
\hline 1 & $.859^{\mathrm{a}}$ & .738 & .728 & 2.418 \\
\hline
\end{tabular}

a. Predictors : (Constant), Kompensasi, Promosi_Jabatan, Lingkungan_Kerja

Sumber : Data Diolah Dari Hasil Penelitian, 2019

Berdasarkan tabel 9. dapat diketahui bahwa hasil uji koefisien korelasi linear berganda untuk pengaruh antara variabel lingkungan kerja, promosi jabatan dan kompensasi terhadap kinerja karyawan adalah 0,859 yang berada pada interval koefisien antara 0,800-1,000 dengan tingkat hubungan yang sangat kuat. Hal ini berarti lingkungan kerja, promosi jabatan dan kompensasi mempunyai pengaruh yang sangat kuat terhadap kinerja karyawan pada CV. Kesuma Jaya Medan. Berdasarkan tabel 9. maka dapat disimpulkan bahwa uji koefisien korelasi linear berganda untuk pengaruh di antara variabel lingkungan kerja, promosi jabatan dan kompensasi terhadap kinerja karyawan adalah sangat kuat.

Uji Hipotesis Secara Parsial atau Uji t

Hasil uji hipotesis parsial atau uji t untuk pengaruh di antara variabel lingkungan kerja, promosi jabatan dan kompensasi secara individual dalam menerangkan kinerja karyawan dapat dilihat pada tabel 7 di atas.

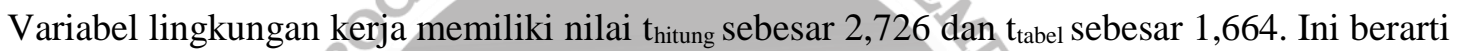
$t_{\text {hitung }}>t_{\text {tabel }}$. Nilai signifikasi variabel lingkungan kerja adalah 0,008 dimana nilai signifikasi ini lebih kecil dari nilai alpha $(0,05)$. Dengan melihat perbandingan nilai $t_{\text {hitung }}$ dan $t_{\text {tabel }}$ serta melihat nilai signifikasi, dapat ditarik kesimpulan bahwa $\mathrm{H}_{0}$ ditolak dan $\mathrm{H}_{\mathrm{a}}$ diterima. Oleh karena itu, dapat ditarik kesimpulan bahwa lingkungan kerja berpengaruh positif dan signifikan terhadap kinerja karyawan di CV Kesuma Jaya Medan.

Variabel promosi jabatan memiliki nilai $t_{\text {hitung }}$ sebesar 4,999 dan $t_{\text {tabel }}$ sebesar 1,664. Ini berarti $t_{\text {hitung }}>t_{\text {tabel }}$. Nilai signifikasi variabel promosi jabatan adalah 0,000 dimana nilai signifikasi ini lebih kecil dari nilai alpha $(0,05)$. Dengan melihat perbandingan nilai $t_{\text {hitung }}$ dan $t_{\text {tabel }}$ serta melihat nilai signifikasi, dapat ditarik kesimpulan bahwa $\mathrm{H}_{0}$ ditolak dan $\mathrm{H}_{\mathrm{a}}$ diterima. Oleh karena itu, dapat ditarik kesimpulan bahwa promosi jabatan berpengaruh positif dan signifikan terhadap kinerja karyawan di CV Kesuma Jaya Medan.

Variabel kompensasi memiliki nilai $t_{\text {hitung }}$ sebesar 2,212 dan $t_{\text {tabel }}$ sebesar 1,664. Ini berarti $t_{\text {hitung }}$ $>t_{\text {tabel }}$. Nilai signifikasi variabel kompensassi adalah 0,030 dimana nilai signifikasi ini lebih kecil dari nilai alpha $(0,05)$. Dengan melihat perbandingan nilai $t_{\text {hitung }}$ dan $t_{\text {tabel }}$ serta melihat nilai signifikasi, dapat ditarik kesimpulan bahwa $\mathrm{H}_{0}$ ditolak dan $\mathrm{H}_{\mathrm{a}}$ diterima. Oleh karena itu, dapat ditarik kesimpulan bahwa kompensasi berpengaruh positif dan signifikan terhadap kinerja karyawan di CV Kesuma Jaya Medan. Uji Hipotesis Simultan atau Uji F

Hasil uji hipotesis secara simultan atau uji $\mathrm{F}$ untuk pengaruh di antara variabel lingkungan kerja, variabel promosi jabatandan variabel kompensasisecara bersama-sama terhadap variabel kinerja karyawan dapat dilihat pada tabel 11. berikut:

Tabel 11. Hasil Uji Hipotesis Simultan Atau Uji F Untuk Pengaruh Antara Variabel Lingkungan Kerja, Variabel Promosi Jabatan Dan Variabel Kompensasi Secara BersamaSama Terhadap Variabel Kinerja Karyawan

\begin{tabular}{|c|c|c|c|c|c|c|}
\hline \multicolumn{7}{|c|}{ ANOVA $^{\mathrm{a}}$} \\
\hline \multicolumn{2}{|c|}{ Model } & Sum of Squares & $\mathrm{df}$ & Mean Square & $\mathrm{F}$ & Sig. \\
\hline \multirow[t]{3}{*}{1} & Regression & 1316.204 & 3 & 438.735 & 75.070 & $.000^{\mathrm{b}}$ \\
\hline & Residual & 467.546 & 80 & 5.844 & & \\
\hline & Total & 1783.750 & 83 & & & \\
\hline
\end{tabular}

a. Dependent Variable: Kinerja_Karyawan

a. Predictors: (Constant), Kompensasi, Promosi_Jabatan, Lingkungan_Kerja

Sumber: Data Diolah Dari Hasil Penelitian, 2019

Berdasarkan tabel 11 .dapat diketahui bahwa $F_{h i t u n g}$ yang dihasilkan dari uji hipotesis secara simultan atau uji $\mathrm{F}$ untuk pengaruh variabel lingkungan kerja, promosi jabatan dan 


\section{Volume 20 Nomor 2, September 2020}

kompensasi secara bersama-sama terhadap kinerja karyawan adalah 75,070; sedangkan

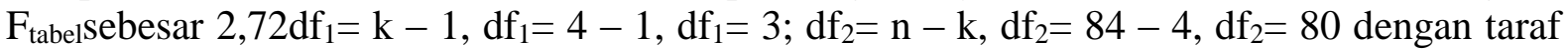
kesalahan 5\%), hal ini berarti $F_{\text {hitung }}>F_{\text {tabel }}(75,070>2,72)$ yang artinya bahwa variabel lingkungan kerja, promosi jabatan dan kompensasi mempunyai pengaruh yang positif dan signifikan terhadap kinerja karyawan padaCV. Kesuma Jaya Medan. Hasil perhitungan koefisien determinasi untuk kontribusi di antara variabel lingkungan kerja, promosi jabatan dan kompensasi terhadap kinerja karyawan adalah 0,728 atau $72,8 \%$. Hal ini menunjukkan bahwa kontribusi dari variabel lingkungan kerja, promosi jabatandan kompensasi untuk meningkatkan variabel kinerja karyawan adalah sebesar 0,728 atau 72,8\%, sedangkan sisa 0,272 atau 27,2\% dipengaruhi oleh variabel lain yang tidak diteliti di dalam penelitian ini, sepertikepemimpinan, komitmen kerja, budaya organisasi dan lain sebagainya.

\section{PEMBAHASAN}

\section{Pengaruh Lingkungan Kerja Terhadap Kinerja Karyawan}

Menurut Sedarmayati(2017:1), mendefinisikan lingkungan kerja adalah keseluruhan alat perkakas dan bahan yang dihadapi lingkungan sekitarnya dimana seseorang bekerja mencakup metodekerjanya, serta pengaturan kerjanya baik sebagai perseorangan maupun sebagai kelompok. Hal ini didukung keseluruhan jawaban responden untuk pernyataan dari variabel lingkungan kerjaterdapat $75,1 \%$ responden yang memilih jawaban sangat setuju dan jawaban setuju. Hal ini menunjukkan bahwa lingkungan kerja dalam perusahaan ini dikategorikan baik, sedangkan dari keseluruhan jawaban responden terdapat $4,7 \%$ responden yang memilih jawaban tidak setuju. Berdasarkan hasil uji hipotesis parsial atau uji t di atas, maka dapat disimpulkan bahwa lingkungan kerja mempunyai pengaruh yang positif dan signifikan terhadap kinerja karyawan pada CV. Kesuma Jaya Medan.

\section{Pengaruh Promosi Jabatan Terhadap Kinerja Karyawan}

Menurut Hasibuan (2016:108), promosi adalah perpindahan yang memperbesar wewenang dan tanggung jawab karyawan ke jabatan yang lebih tinggi di dalam suatu organisasi sehingga kewajiban, hak, status, dan penghasilannya semakin besar.

Hal ini didukung keseluruhan jawaban responden untuk pernyataan dari variabel promosi jabatanterdapat $70,2 \%$ responden yang memilih jawaban sangat setuju dan jawaban setuju. Hal ini menunjukkan bahwa promosi jabatan dalam perusahaan ini dikategorikan baik, sedangkan dari keseluruhan jawaban responden terdapat 3,9\% responden yang memilih jawaban tidak setuju. Berdasarkan hasil uji hipotesis parsial atau uji t di atas, maka dapat disimpulkan bahwa promosi jabatan mempunyai pengaruh yang positif dan signifikan terhadap kinerja karyawan padaCV. Kesuma Jaya Medan.

\section{Pengaruh Kompensasi Terhadap Kinerja Karyawan}

Menurut Handoko (2014:155) Kompensasi adalah segala sesuatu yang diterima oleh pekerja sebagai balas jasa atas kerja mereka. Sedangkan menurut Hasibuan (2016:118) kompensasi adalah semua pendapatan yang berbentuk uang, barang langsung atau tidak langsung yang diterima karyawan sebagai imbalan atas yang diberikan kepada perusahaan. Hal ini didukung keseluruhan jawaban responden untuk pernyataan dari variabel kompensasi terdapat $76,2 \%$ responden yang memilih jawaban sangat setuju dan jawaban setuju. Hal ini menunjukkan bahwa kompensasi dalam perusahaan ini dikategorikan baik, sedangkan dari keseluruhan jawaban responden terdapat 3,5\% responden yang memilih jawaban tidak setuju. Berdasarkan hasil uji hipotesis parsial atau uji $t$ di atas, maka dapat disimpulkan bahwa kompensasi mempunyai pengaruh yang positif dan signifikan terhadap kinerja karyawan pada CV. Kesuma Jaya Medan.

Pengaruh Lingkungan Kerja, Promosi Jabatan dan Kompensasi Terhadap Kinerja Karyawan 


\section{Volume 20 Nomor 2, September 2020}

Lingkungan kerja, promosi jabatan dan kompensasi mempunyai peranan yang sangat penting dalam meningkatkan kinerja karyawan. Hal ini didukung keseluruhan jawaban responden untuk pernyataan dari variabel kinerja karyawan terdapat $75,5 \%$ responden yang memilih jawaban sangat setuju dan jawaban setuju. Hal ini menunjukkan bahwa kinerja karyawan dalam perusahaan ini dikategorikan baik, sedangkan dari keseluruhan jawaban responden terdapat 2,3\% responden yang memilih jawaban tidak setuju. Berdasarkan hasil uji hipotesis simultan atau uji $\mathrm{F}$ di atas, maka dapat disimpulkan bahwa lingkungan kerja, promosi jabatan dan kompensasi mempunyai pengaruh yang positif dan signifikan terhadap kinerja karyawan padaCV. Kesuma Jaya Medan.

\section{Kesimpulan}

\section{KESIMPULAN DAN SARAN}

Berdasarkan hasil analisis deskriptif untuk variabel lingkungan kerja, promosi jabatan, kompensasi dan kinerja karyawan berada dalam kategori baik padaCV. Kesuma Jaya Medan. Berdasarkan hasil uji t lingkungan kerja mempunyai pengaruh yang positif dan signifikan terhadap kinerja karyawan pada CV. Kesuma Jaya Medan dimana hal ini mengindikasikan bahwa semakin baik kondisi lingkungan kerja yang diterapkan oleh pimpinan perusahaan, maka kinerja yang dihasilkan oleh karyawan akan semakin meningkat. Hasil uji t untuk promosi jabatan mempunyai pengaruh yang positif dan signifikan terhadap kinerja karyawan pada CV. Kesuma Jaya Medan dimana hal ini mengindikasikan bahwa semakin jelas sistem promosi jabatan yang diterapkan oleh pimpinan perusahaan, maka kinerja yang dihasilkan oleh karyawan akan semakin meningkat.Hasil uji t untuk kompensasi mempunyai pengaruh yang positif, dan signifikan terhadap kinerja karyawan pada CV. Kesuma Jaya Medan dimana hal ini mengindikasikan bahwa tinggi kompensasi yang diberikan kepada karyawan akan meningkatkan kinerja karyawan. Berdasarkan hasil uji $\mathrm{F}$ untuk variabel lingkungan kerja, promosi jabatan dan kompensasi mempunyai pengaruh yang positif dan signifikan terhadap kinerja karyawan pada CV. Kesuma Jaya Medan dimana hal ini mengindikasikan bahwa semakin baik kondisi lingkungan kerja, semakin jelas sistem promosi jabatandan semakin tinggi kompensasi yang diberikan kepada karyawan, maka kinerja karyawan akan semakin meningkat.Hasil perhitungan koefisien determinasi menunjukkan bahwa kontribusi dari variabel lingkungan kerja, promosi jabatan dan variabel kompensasi untuk meningkatkan variabel kinerja karyawan pada CV. Kesuma Jaya Medanadalah sebesar 0,728 atau 72,8\%, sedangkan sisa 0,272 atau $27,2 \%$, dipengaruhi oleh variabel lain yang tidak diteliti oleh penulis di dalam penelitian ini, seperti kepemimpinan, komitmen kerja, budaya organisasi, dan lain sebagainya.

\section{Saran}

Untuk variabel lingkungan kerja; penerangan di ruangan diharapkan dibuat senyaman mungkin, lampu yang digunakan untuk penerangan diharapkan berfungsi dengan baik dan cat yang digunakan tidak membuat ruangan tampak gelap.Untuk variabel promosi jabatan; diharapkan agar kerjasama antar lini berjalan dengan baik, kerjasama tim berjalan dengan baik dan mengurangi tingkat pengunduran diri yang tinggi.

Untuk variabel kompensasi ; diharapkan agar gaji yang diterima karyawan mencukupi kebutuhan sehari-hari, gaji yang diterima karyawan sesuai dengan hasil pekerjaan yang diberikan kepada perusahaan dan karyawan mendapat bonus tahunan yang layak. Untuk variabel kinerja ; diharapkan agar memberi upaya supaya karyawan menyelesaikan pekerjaan secara tepat waktu dan karyawan dituntut untuk memiliki sikap tanggung jawab.

\section{DAFTAR PUSTAKA}

Sugiyono, 2008, Metode Penelitian Bisnis, CV.Alfabeta, Bandung

Rivai,H.Veithzal.2011.Manajemenen Sumber Daya Manusia Untuk Perusahaan.Jakarta: Rajawali Pers

Sedarmayanti. 2011. Tata Kerja dan Produktivitas Kerja. Bandung: CV. Mandar Maju. Mangkunegara, A. P. 2010. Manajemen Sumber Daya Manusia Perusahaan. Bandung: 
Ghozali, Imam. 2009. Aplikasi Analisis Multivariate Dengan Program SPSS. Edisi Keempat, Semarang: Universitas Diponegoro.

Sedarmayanti. 2011. Tata Kerja dan Produktivitas Kerja. Bandung: CV. Mandar Maju.

Siagian, Sondang P. 2003. Manajemen Sumber Daya Manusia. Jakarta : Bumi aksara.

Mangkunegara, Anwar P 2008. Manajemen Sumber Daya Manusia Perusahaan. Bandung:

PT.

Remaja Rosdakarya.

Handoko T. Hani. 2001. Manajemen Personalia dan Sumber daya Manusia. Edisi 2. Yogyakarta : BPFE

Hasibuan, Malayu SP. 2016. Manajemen Sumber Daya Manusia, Edisi Revisi. Jakarta:

Bumi Aksara.

Gozali, Imam. 2006. Aplikasi Analisis Multivariate dengan Program SPSS. Semarang: BP UNDIP. Arikunto, Suharsimi. 2006. Prosedur Penelitian Suatu Pendekatan Praktek. Jakarta: Rineka Cipta Simamora, Henry, 2004. Manajemen Sumber Daya Manusia. Edisi Kedua.STIE : YKPN

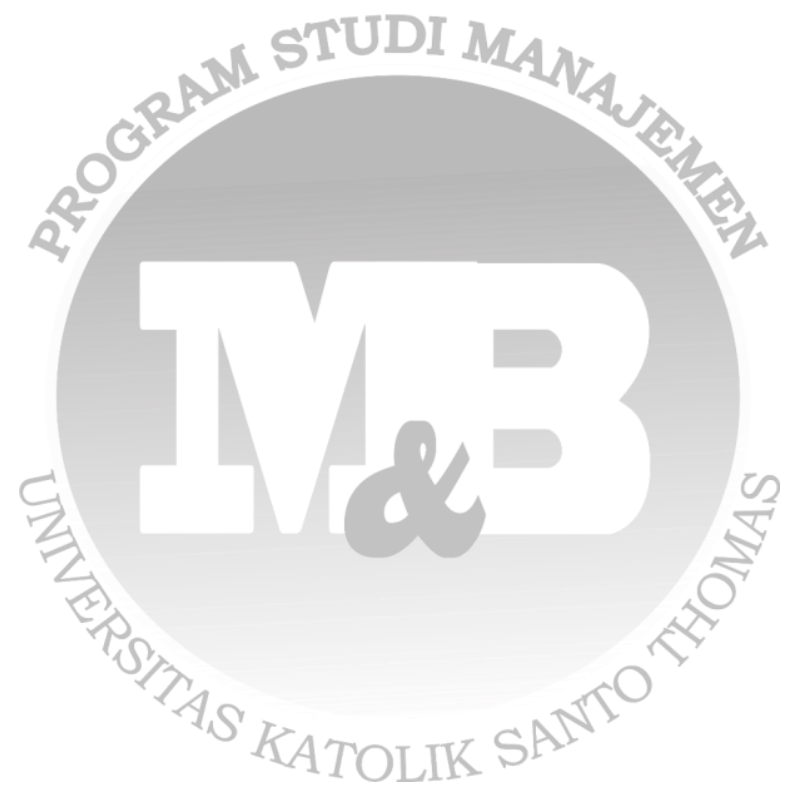

